\title{
Alteration of Red Cell Membrane Subunit Pattern after Pronase Treatment
}

\author{
By Ina Sprenger, K. Felgenhauer, M. Nekic and G. Uhlenbruck \\ From the Medical and Neurological Clinics of the University of Cologne
}

(Eingegangen am 27. November 1971)

\begin{abstract}
The effect of pronase on pig red blood cells has been studied. Membranes of normal and Pronase-treated red cells, as well as the mucopeptide released by pronase treatment, were compared by solubilization in sodium dodccylsulfate followed by separation into their single components by electrophoresis on polyacrylamide gels. A sialoglycoprotein was released, which was homogeneous and had a molecular weight of 25.000 . A residual $50.000 \mathrm{MW}$ glycopeptide remained in the membrane.
\end{abstract}

Die Wirkung von Pronase auf Schweineerythrocyten wurde analysiert. Membranen unbehandelter und Pronase-behandelter Erythrocyten sowie das durch die Pronasebehandlung abgespaltene Mucopeptid wurden in Natrium-Dodecylsulfat gelöst und in der Polyacrylamidgelelektrophorese in ihre einzelnen Komponenten aufgetrennt. Im Wesentlichen wurde cin Sialoglykoprotein (MW 25.000) abgespalten, während in der Pronase-behandelten Membran ein neues Glykopeptid (MW 50.000) entstand.

In a recent review, the chemical composition and biological importance of red cell membrane glycoproteins were extensively summarized $(1,2)$ and it was stressed that the topographical arrangement of the glycoproteins within the membrane may deserve closer attention. A scheme has also been outlined $(3,4,5)$ for differentiating between the different possible topographies of the various glycoproteins.

Our experimental approach to the investigation of these topographical problems is to treat the intact red blood cell with enzymes, assuming that only glycoproteins localized on the outside of the membrane will be released. It was subsequently possible to compare the constitution of the treated membrane with that of the untreated membrane. A prerequisite of these investigations is the solubilization of the membrane proteins and their fractionation into single constituents by an appropriate method. We solubilized the membrane in sodium dodecylsulfate, followed by electrophoretic fractionation in sodium dodecylsulfate containing polyacrylamide gels. Since sodium dodecylsulfate is a very effective membrane solubilizer, it is widely used to characterize membrane proteins $(2-6)$. The electrophoretic mobilities of complexes between proteins and sodium dodecylsulfate generally do not depend on protein shape or charge, but only on molecular weight $(7,8,9)$. The molecular weights of proteins containing great amounts of carbohydrate tend to be to high, when determined by this method (10); Since the binding ratio and velocities as well as the dissociation kinetics vary greatly from protein to protein (11), we have chosen to apply the drastic solubilization procedure of Glossmann and Lutz (12). Only then can a complet subunit dissociation be expected.

\section{Material and Methods}

Preparation of exythrocyte ghosts

Ghosts were prepared according to the method of MADDY (13) which followed the principles of hypotonic lysis reported by DODGE and coworkers (14). We prepared ghosts from native red cells (I) and from pronase-treated red cells (II). Fresh blood from one pig was collected into $3.8 \%$ citrate and then the serum and white cells removed by washing three times in isotonic saline. The erythrocytes were haemolysed in 5 vol. of $5 \mathrm{~mm}$ phosphate buffer ( $\mathrm{pH}$ 6.0). The ghosts were collected from the hacmolysate by centrifugation at $18000 \mathrm{~g}$ for $15 \mathrm{~min}$ and washed repeatedly with this buffer until the supernatant was free of haemoglobin. The remaining haemoglobin was removed by washing with $5 \mathrm{~nm}$ buffer at $\mathrm{pH}$ 8.0. The final preparation was pale pink in colour and contained less than $0.1 \%$ haemoglobin. The ghosts were intact in shape and their serological specificity did not differ from that of the native cell.

\section{Enzyme treatment of red cells}

The red cells were treated with a $0.01 \%$ enzyme solution (pronase B low grade, Calbiochem) in $0.9 \% \mathrm{NaCl}, \mathrm{pH} 7.0$, for $45 \mathrm{~min}$ at $37^{\circ}$. The incubation mixture was centrifuged, and the cells were washed and haemolysed to prepare ghosts.

Isolation of mucopeptides from the red cell

Erythrocyte mucopeptide (III) was prepared by phenol-saline extraction from the supernatant of the incubation mixture after the treatment of red cells with pronase (15). The water layer was dialysed against distilled water and subsequently freeze-dried.

Dissolution of membrane proteins and mucopeptides in sodium dodecylsulfate and electrophoretic fractionation in polyacrylamide gels containing sodium dodecylsulfate

The samples were dissolved in $4 \mathrm{M}$ urca, $1 \%$ sodium dodecylsulfate and $1 \%$ ethylmercaptoethanol by heating for $3 \mathrm{~min}$ at $95^{\circ}$ (12). Alkylation was performed after cooling to $4^{\circ}$ with the aid of $10 \%$ molar excess of iodoacetamide. Prior to electrophoresis, $25 \%$ glucose is added and bromphenolred is used as marker. For the electrophoretic separation the ORNSTISIN-Davis discontinuous principle $(16,17)$ as modified by GLOsSMaNN and LUTz (12) was applied. 
Lower gel: $10 \mathrm{~cm}$ length, $8 \%$ and $12 \%$ acrylamide, $0.375 \mathrm{M}$ Tris- $\mathrm{HCl}$ buffer $\mathrm{pH} 8.8$.

Upper gel: $2.5 \mathrm{~cm}$ length, $3 \%$ acrylamide, $0.063 \mathrm{M}$ Tris $-\mathrm{H}_{2} \mathrm{SO}_{4}$ buffer $\mathrm{pH} 6.8$.

Conditions common to both gels: Monomer to comonomer (bisacrylamide) $=37.5: 1.100 \mathrm{mg} / 100 \mathrm{ml}$ ammoniumpersulfate, $0.1 \%$ sodium dodecylsulfate, TEMED was $1.12 \%$ and $\mathrm{K}_{3} \mathrm{Fc}(\mathrm{CN})_{6}$ was $0.05 \%$ that of actylamide concentration in each gel.

Proteins were stained for 3 hours in $0.2 \%$ amidoblack - 5\% acetic acid after pretreatment in $20 \%$ sulfosalicylic acid for 16 hours. The glycoproteins were PAS-stained as reported earlier (18).

To calibrate the system, the following proteins were used: horse myoglobin, trypsin, pepsin, ovalbumin, (all from Serva, Heidelberg), catalase (Boehringer, Mannheim) and transferrin (Behringwerke, Marburg). Coefficient of correlation: -0.98 (log MW versus $R_{\mathrm{F}}$-bromphenolred).

Densitometry and photographic alignment of the curves were performed as previously described (18).

\section{Results and Discussion}

The aim of our investigations was to establish the peptide and glycopeptide pattern of pig red cell membranes using a very drastic dissociation method, before and after pronase treatment. We wished to ensure that a complete dissociation of each type of bond (hydrogen bonds, S-S bonds, hydrophilic and hydrophobic bonds) had taken place. Preliminary experiments with proteins of known subunit structure show that this can only be accomplished by using a mixture of sodium dodecylsulfate, urea and ethylmercaptoethanol with heating to $95^{\circ}$. Alkylation is nessessary to prevent correct or incorrect (hybrid formation) reassociation of sulfhydryl bonds. In this context, we define the term "subunit" as referring to a peptide with or without carbohydrate group. Since the stability of membrane components is not known, milder treatment may lead to incomplete dissociation and may be responsible for the discrepancies in the band pattern reported by different authors. Accordingly, the high proportion of small molecular weight subunits is not surprising. On the other hand, it has to be remembered that proteases may act on the membrane proteins even with careful handling of the preparations, and This would also result in low molecular weight subunits.

Pig erythrocyte membranes have been analyzed as:

(I) total membranes

(II) membranes after pronase treatment

(III) mucopeptides split off by pronase treatment.

The subunit patterns of the three samples are given in Fig. $1-3$. The pattern of the untreated membrane (I) is given in Fig. 1: the two dominant glycopeptides, MW 8,000 and 38,000 , can be assumed to have a very high carbohydrate content, since they are no longer apparent when the bulk of the peptides is stained with amido black. The proportion of high molecular subunits above $66,000 \mathrm{MW}$ (see also Fig. 2a) is surprisingly high in view of the quite rough solubilization procedure.

Fig. 2 shows the subunit pattern of the membrane after pronase treatment (II): as expected the proportion of

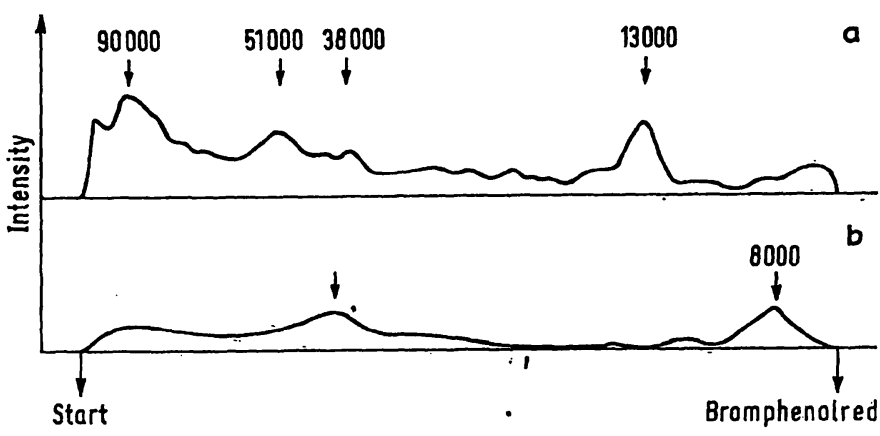

Fig. 1 Subunit composition of pig erythrocyte membranes after treatment
with sodium dodecylsulfate, urea and ethylmercaptoethanol at $95^{\circ}$. with sodium dodecylsulfate, urea and ethylmercaptoethanol at $95^{\circ}$. $12 \%$ arcylamide gel. Curves are brought to the same
graphically. Bromphenolred $=R_{F} 100$ graphically. Bromphenolred $=R_{F}$
a. amidoblack; b. PAS staining a. amidoblack; $b$. PAS stainin
Curve interpretation see text

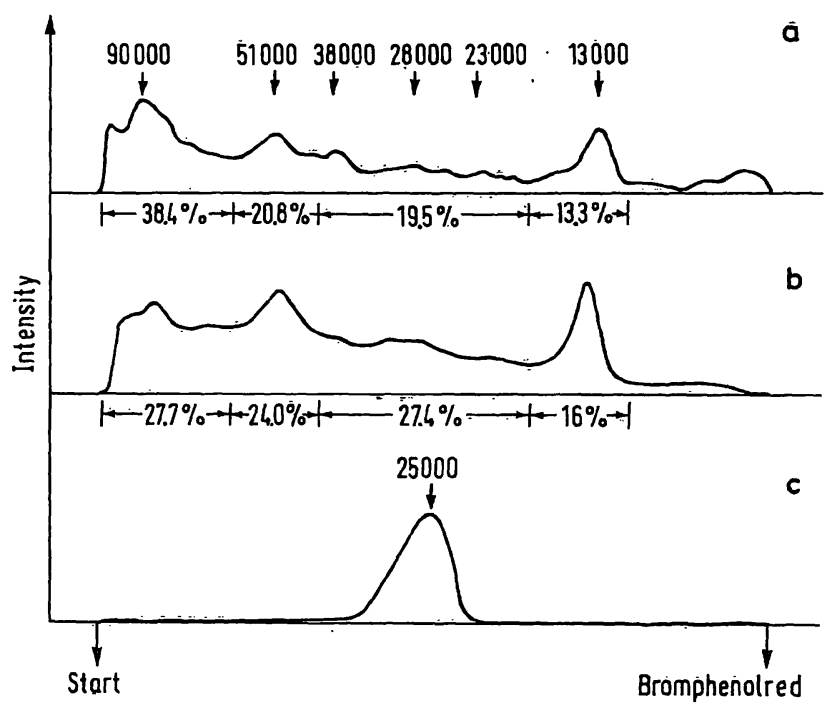

Fig. 2

Subunit composition of pig erythrocyte membranes before $(a)$ and after $(b)$ pronase treatment as revealed by amidoblack staining. c. liberated glycopeptide (III). PAS-staining

high molecular weight material decreases (by $11 \%$ ), mainly in favor of a subunit family between 18,000 and $40,000 \mathrm{MW}$ ( $8 \%$ increase). Only one single $25,000 \mathrm{MW}$ sialoglycoprotein is liberated from the membrane; even when $1 \mathrm{mg}$ substance is applied this cannot be stained with amidoblack, but is easily detectable with the PAS staining, what indicates its high content of carbohydrate groups.

After pronase treatment, a residual 50,000 MW membrane glycopeptide becomes detectable (Fig. 3). The persistently high proportion of high molecular weight glycopeptides after enzyme treatment is somewhat surprising. Very probably these components are sodium dodecylsulfate-resistant parts of the membrane, which become sodium dodecylsulfate-soluble only after pronase treatment.

The action of pronase on pig red cell membranes is characterized in summary as the following:

(1) A very carbohydrate-rich $25,000 \mathrm{MW}$ sialoglycoprotein is released from the membrane.

(2) The remaining 50,000 MW membrane glycopeptide residue becomes detectable. 


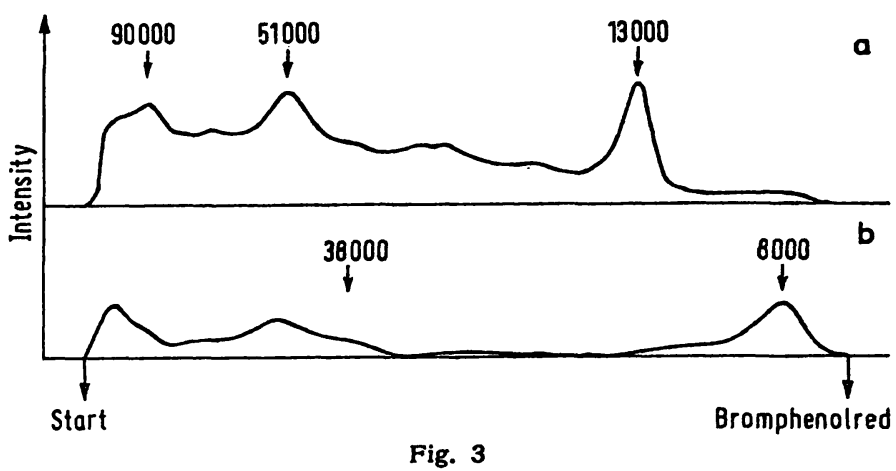

Subunit composition of pig erythrocyte membranes after pronase a. amidoblack staining; b. PAS staining

(3) Low molecular weight peptides within the membrane $(18,000-40,000)$ increase, while high molecular peptides decrease.

BENDER and coworker (6) in a similar experimental approach with human cells, found that pronase acted on a $125,000 \mathrm{MW}$ glycoprotein, leaving a 73,000 protein in the membrane. In contrast with these results, our peptide remaining in the pig erythrocyte membrane had a molecular weight of only 50,000 . It is uncertain, whether these discrepancies are due to species differences or to the more drastic solubilization procedure used by us. Since BENDER and coworker used only sodium dodecylsulfate, disulfide bridges may still be intact and prevent complete subunit dissociation. Nevertheless, the molecular weight difference produced by pronase action is about 50,000 in both cases and we could show definitely, that the released mucopeptide, giving only one single band in sodium dodecylsulfate disc electrophoresis, is not larger than 25,000 .

\section{Acknowledgement}

The technical assistance of Mrs. Mardies Heggen is greatfully appreciated. This work was supported by the Deutsche Forschungsgemeinschaft.

\section{References}

1. Uhlenbruck, G., Chimia 25, 10 (1971). - 2. Zahler, P., Schweiz. med. Wschr. 101, 1490 (1971). - 3. BRETSCHER, M. S., Nature New Biol. 231, 229 (1971). - 4. Farrbanks, G., T. L. STECK and D. F. H. WALLACH, Biochemistry 10, 2606 (1971). 5. STECK, T. L., G. FAirbanks and D. F. H. WALlaCh, Biochemistry 10, 2617 (1971). - 6. BENDER, W. W., H. GARAN and H. C. Berg, J. Mol. Biol. 58, 783 (1971). - 7. Shapiro, A. L., E. Vinuela and J. V. Maizel, Biochem. Biophys. Res. Comm. 28, 815 (1967). - 8. Shapiro, A. L. and J. V. Matzel, Analytic. Biochem. 29, 505 (1969). - 9. DUNKER, A. K. and R. R. RUEKKERT, J. biol. Chemistry 244, 5074 (1969). - 10. SEgREST, J. P., R. L. Jackson, E. P. Andrews and V. T. MArchesi, Biochem.
Biophys. Res. Comm. 44, 390 (1971). - 11. Nelson, C. A., J. biol. Chemistry 246, 3895 (1971). - 12. Glossmand, H. and F. Lurz, Hoppe-Seyler's Z. physiol. Chem. 351, 1583 (1970). 13. Maddy, A. H., Biochim. biophysica Acta, Amsterdam 117, 193 (1966). - 14. Dodge, J. T., C. Mrtchell and D. J. Hanahan, Arch. Biochem. Biophysics 100, 119 (1963). - 15. KLENK, E. and G. Uhlendruck, Hoppe-Seyler's Z. physiol. Chem. 319, 151 (1960). - 16. Ornstern, L., Ann. N. Y. Acad. Sci. 121, 321 (1964). - 17. Davrs, B. J., Ann. N. Y. Acad. Sci. 121, 404 (1964). 18. Felgenhauer, K., Clin. Chim. Acta, Amsterdam 27, 305 (1970).
Prof. Dr. G. Uhlenbruck and Dr. I. Sprenger Abteilung für Immunbiologie

5 Köln 41

Kerpener Str. 15

Priv. Doz. Dr. K. Felgenhauer and M. Nekic Nervenklinik

5 Köln 41

Josef-Stelzmann-Str. 9 